\title{
Genetic Diversity of Egyptian Barley Cultivars for Water Stress using SSR Markers
}

\author{
Samah A. Mariey ${ }^{1}$, Mona A.M. El-Mansoury ${ }^{2}$, Amin M.E Agwa ${ }^{1}$ and Mary E. Nashed ${ }^{3}$ \\ ${ }^{1}$ Barley Res., Department, Field Crops Research Institute, Agricultural Research Center, Egypt \\ ${ }^{2}$ Soils, Water and Environment Res. Inst., Agric. Res. Center, Giza, Egypt \\ ${ }^{3}$ Crop Physiology Res., Department, Field Crops Research Institute, Agricultural Research Center, Egypt
}

Received: 20 Dec. 2019 / Accepted 30 Jan. 2020 / Publication date: 20 Feb. 2020

\begin{abstract}
Abiotic stresses in particular water stress which was considered important stress that affecting all crops in all the world and Egypt. The aim of the present work was to evaluate the performance of 15 Egyptian barley cultivars and find out the genetic diversity of these cultivars for water stress tolerance using simple sequence repeats (SSR) during two consecutive seasons to detect their tolerance to water stress. Results revealed that the Egyptian barley Giza 126, Giza 131 and Giza 2000 were considered as tolerant cultivars, which they exhibited the highest mean values for all studied morphological and physiological traits. Twenty alleles were produced as a result of fingerprinting ten SSR primers ranging from one to four alleles per locus with a mean value of 2.0 alleles per locus. The PIC (Polymorphism Information Content) value of each SSR marker ranged from 0.23 ( HvM67) to 0.58 (EBmac 624) with an average value of 0.227. Un-weighted Pair-Group Method with Arithmetic (UPGMA) cluster analysis of the similarity data grouped all the fifteen studied Egyptian cultivars into two major groups divided according to their response to water stress tolerance; first group include all the water stress tolerant cultivars and moderately tolerant in two closely related clusters, while all the sensitive genotypes and moderate cultivars in the other group were closely related in two clusters. These results proposed that SSR markers are professional and detective tool for assessment of genetic diversity and relatedness as well as distinguishing the Egyptian barley cultivars for water stress tolerance to use them in breeding program.
\end{abstract}

Keywords: Hordeum vulgare L., morphological and physiological traits, water stress tolerance, SSR marker, PIC, UPGMA cluster analysis.

\section{Introduction}

Abiotic stresses in particular water stress, constrain the global production of crops, affecting both the vegetative and reproductive phases of development (Wang et al., 2003). Water stress is one of the most important aggressive factors for plant production in the arid and semi-arid regions of the world, which affects morphological, physiological, biochemical and molecular processes in plants. (Zhao et al., 2008).

Barley (Hordeum vulgare L.) is the fourth most cultivated cereal crop worldwide, which barley was considered the first important winter cereal crop grown in arid and semi-arid regions in North Africa, because of its earliness, ability to escape terminal drought-stress, and grown in areas where irrigation is poorly available. (Ceccarelli et al., 1987). Barley is also considered as a good model species for cereals due to its commonly accessible genetic information (Hayes et al., 2000).

Estimation of genetic relationship and genetic diversity have always been important goal for breeders (Meszaros et al., 2007), because success in breeding purposes, utilization and effective conservation of genetic resources depend on correct estimations of these parameters. Morphological markers have been used to evaluate genetic diversity. However, due to the limited number of indicators and impact of environmental factors on morphological. (Zhang et al., 2002). Assessment of genetic diversity using molecular markers is one of the primary and important steps in breeding programs (Vahideh Gougerdchi et al., 2014). DNA markers were unbiased by environmental conditions; this is why molecular methods are appropriate alternative for morphological criteria (Pirseyedi et al., 2006). Simple sequence repeats (SSRs) markers that are based on the polymerase chain reaction (PCR) have possessions like high level polymorphism, co-dominant inheritance, highly reproducibility, locus specificity and random distribution on the genome (Russell et al., 1997), which 
all of these advantages make SSR markers as a superior markers for evaluation of genetic diversity, genetic relationship and phylogenetic development. Using SSRs technique as powerful tool for genetic studies in barley breeding for drought (water) stress have been frequently confirmed in several investigations such as (Lakew et al.. 2012; El Rabey et al., 2012; Vahideh Gougerdchi et al., 2015; Hellal et al., 2018 and Heiba et al., 2019 ).

The powerful techniques to detect the molecular basis of plant adaptation to its environment and phenotype could be provided by combine advanced molecular technologies with conventional breeding and physiological techniques (Said et al., 2015)

The present study aimed to investigate the genetic diversity of 15 Egyptian barley cultivars for water stress tolerance in order to classify them on the SSR molecular level and to study relative importance of some physiological and molecular marks to provide genetic information for the future breeding programs for water stress to increase the production in the new reclaimed lands under different irrigation systems

\section{Materials and Methods}

\section{Plant Material:}

Fifteen Egyptians barley cultivars kindly provided by Sakha Barley Research Department, Field Crops Research Institute, Agricultural Research Center, Egypt, are used in this study their, names, row, type and pedigree were shown in (Table 1).

Table 1: Name, row type and pedigree of 15 barley cultivars used in the field experimental

\begin{tabular}{|c|c|c|c|c|c|}
\hline No. & Name & & type & Pedigree & $\begin{array}{l}\text { Year of } \\
\text { released }\end{array}$ \\
\hline 1 & Giza 123 & hulled & Six row & Giza 117/FAO 86 & 1988 \\
\hline 2 & Giza 124 & hulled & Six row & Giza 117/Bahteem 52// Giza 118/FAO 86 & 1995 \\
\hline 3 & Giza 125 & hulled & Six row & $\begin{array}{l}\text { Giza117 / Bahteem52// Giza118 /FAO86(sister line to } \\
\text { G.124 }\end{array}$ & 1995 \\
\hline 4 & Giza 126 & hulled & Six row & Baladi Bahteem/S D729-Por12762-BC. & 1996 \\
\hline 5 & Giza 127 & hulled & Two row & W12291/B0gs//Hamal-02 & 1996 \\
\hline 6 & Giza 128 & hulled & Two row & W12291/4/11012-2170-2242 & 1996 \\
\hline 7 & Giza 129 & hulless & Six row & Deir Alla 106/Cel//As46/Aths*2" & 2001 \\
\hline 8 & Giza 130 & hulless & Six row & Comp.cross"229//Bco.Mr./DZ02391/3/Deir Alla 106 & 2001 \\
\hline 9 & Giza 131 & hulless & Six row & $\begin{array}{l}\text { CM67B/CENTENO//CAMB/3/ROW906.73/4/GLORIA } \\
\text { BAR/ COME-B/5/FALCON BAR/6/LINO }\end{array}$ & 2001 \\
\hline 10 & Giza 132 & hulled & Six row & Rihane-05//AS 46/Aths*2Athe/ Lignee 686 & 2006 \\
\hline 11 & Giza 133 & hulled & Six row & ICB91-0343-0AP-0AP-0AI & 2011 \\
\hline 12 & Giza 134 & hulled & Six row & ICB91-0343-0AP-0AP-0A & 2011 \\
\hline 13 & Giza 135 & hulless & Six row & $\begin{array}{l}\text { ZARZA/BERMEJO/4/DS4931//GLORIABAR/COPAL/3 } \\
\text { /SEN/5/AYAROS }\end{array}$ & 2011 \\
\hline 14 & Giza 136 & hulless & Six row & $\begin{array}{l}\text { PLAISANT/7/CLN-B/LIGEE640/3/S.P-B//GLORIAAR/ } \\
\text { COME B/5/FALCONBAR/6/LINOCLN-B/A/S.P- } \\
\text { /LIGNEE640/3/S.P-B//GLORIA-BAR/COME } \\
\text { B/5/FALCONBAR/6/LINO }\end{array}$ & 2011 \\
\hline 15 & Giza 2000 & hulled & Six row & $\begin{array}{l}\text { Giza117/Bahteem52// Giza118/ FAO86 / 3/Baladi16/ } \\
\text { Gem }\end{array}$ & 2003 \\
\hline
\end{tabular}

\section{Phenotypic Evaluation}

Two separated field experiments were carried out at Sakha Research Farm (North of Egypt), during two winter growing seasons2017/2018 and 2018/2019.The experimental design was performed as randomized complete block combined over environments (irrigation treatments) and seasons with three replicates. The experimental plot consisted of six rows of $3.5 \mathrm{~m}$, spaced out with $20 \mathrm{~cm}$ among rows (sub-plot area $\left.=4.2 \mathrm{~m}^{2}\right)$ while, the main plot area was $\left(4.2 \mathrm{~m}^{2} * 15=63 \mathrm{~m}^{2}\right)$. Plants were individually spaced at $10 \mathrm{~cm}$ within each row. After 70 days from sowing, Total chlorophyll content (SPAD) using chlorophyll meter (SPAD-502 Minolta Camera Co. ltd., Japan) and Proline content $\left(\mathrm{mg} \mathrm{Fwg}^{-1}\right)$ according to Bates et al. (1973) were measured as a physiological characters, and at harvesting stage the measured characters were No. of tillers $\mathrm{m}^{-2}, 1000$-grain weight, grain yield 
$\left(\operatorname{ardfed}^{-1}\right)$, water applied (irrigation water+ rainfall), water consumptive use, Productivity of water applied(PWa) and Water productivity(WP) were calculated according to Ali et al. (2007). It was calculated as follows:

$$
\begin{gathered}
P W a\left(\mathrm{~kg} \mathrm{~m}^{-3}\right)=\frac{\text { Grain yield }\left(\mathrm{kg} \mathrm{fed}^{-1}\right)}{\text { Total amount of water applied }\left(\mathrm{m}^{3} \mathrm{fed}^{-1}\right)} \\
P W\left(\mathrm{~kg} \mathrm{~m}^{-3}\right)=\frac{\text { Grain yield }\left(\mathrm{kg} \mathrm{fed}^{-1}\right)}{\text { Seasonal water consumed by the growing crop }\left(\mathrm{m}^{3} \mathrm{fed}^{-1}\right)}
\end{gathered}
$$

\section{Climatic characteristics prevailing}

Water application was monitored via water meter and some Climatic characteristics such as Monthly means of Maximum and minimum temperature $(\mathrm{T}) \mathrm{C}^{\circ}$, relative humidity $(\mathrm{RH}) \%$, wind speed (Ws), pan evaporation and rainfall during the two seasons at Sakha Res., Station are shown in (Table 2).

Table 2: Mean climatologic data of Sakha during the 2017/18 and 2018/19 seasons.

\begin{tabular}{lccccc}
\hline Month & T $\left(\mathbf{C}^{\mathbf{0}}\right)$ & RH (\%) & $\begin{array}{c}\mathbf{W}_{\mathbf{s}} \\
\left(\mathbf{m ~ s e c}^{-1}\right)\end{array}$ & $\begin{array}{c}\text { Pan Evap. } \\
\left(\mathbf{m m ~ d a y}^{-1}\right)\end{array}$ & $\begin{array}{c}\text { Rainfall (R) } \\
\left(\mathbf{m m ~ m o n t h}^{-1}\right)\end{array}$ \\
\hline Dec.2017 & 20.0 & 76.5 & $\mathbf{2 0 1 7 / 1 8}$ & & \\
Jan.2018 & 18.9 & 76.9 & 0.5 & 1.47 & 5.6 \\
Feb. & 18.0 & 75.6 & 0.5 & 2.62 & 37.4 \\
Mar. & 21.1 & 65.3 & 0.4 & 2.74 & 16.6 \\
April. & 23.9 & 62.4 & 0.5 & 4.24 & 0.0 \\
\hline & & 0.9 & 5.32 & 0.0 \\
Dec.2018 & 16.0 & 76.4 & $\mathbf{2 0 1 8} / \mathbf{1 9}$ & & \\
Jan.2019 & 15.6 & 67.8 & 0.3 & 0.84 & 22.2 \\
Feb. & 17.0 & 72.6 & 0.4 & 1.14 & 14.9 \\
Mar. & 19.7 & 72.2 & 0.3 & 1.78 & 13.0 \\
April. & 23.2 & 64.9 & 0.5 & 2.86 & 17.3 \\
\hline Sar. & & 0.5 & 3.70 & 3.9 \\
\hline
\end{tabular}

Source: Meteorological Station at Sakha Agricultural Research Station $31^{\circ}-07 \mathrm{~N}$ latitude, $30^{\circ}-57 \mathrm{E}$ longitude with an elevation of about 6 meters above mean sea level

\section{Soil characteristics of the experimental site:}

Soil samples were taken in four depths from the soil surface; i.e. $0-15,15-30,30-45 \mathrm{~cm}$ and $15-$ $30 \mathrm{~cm}$. Chemical properties of soil samples from the two isolated field experimental site during the two following seasons, are presented in Table 3. Field experimental samples were analyzed according to Piper (1950) and Black et al., (1965).

Table 3: Soil physical properties, soil moisture constants and chemical properties for studied area.

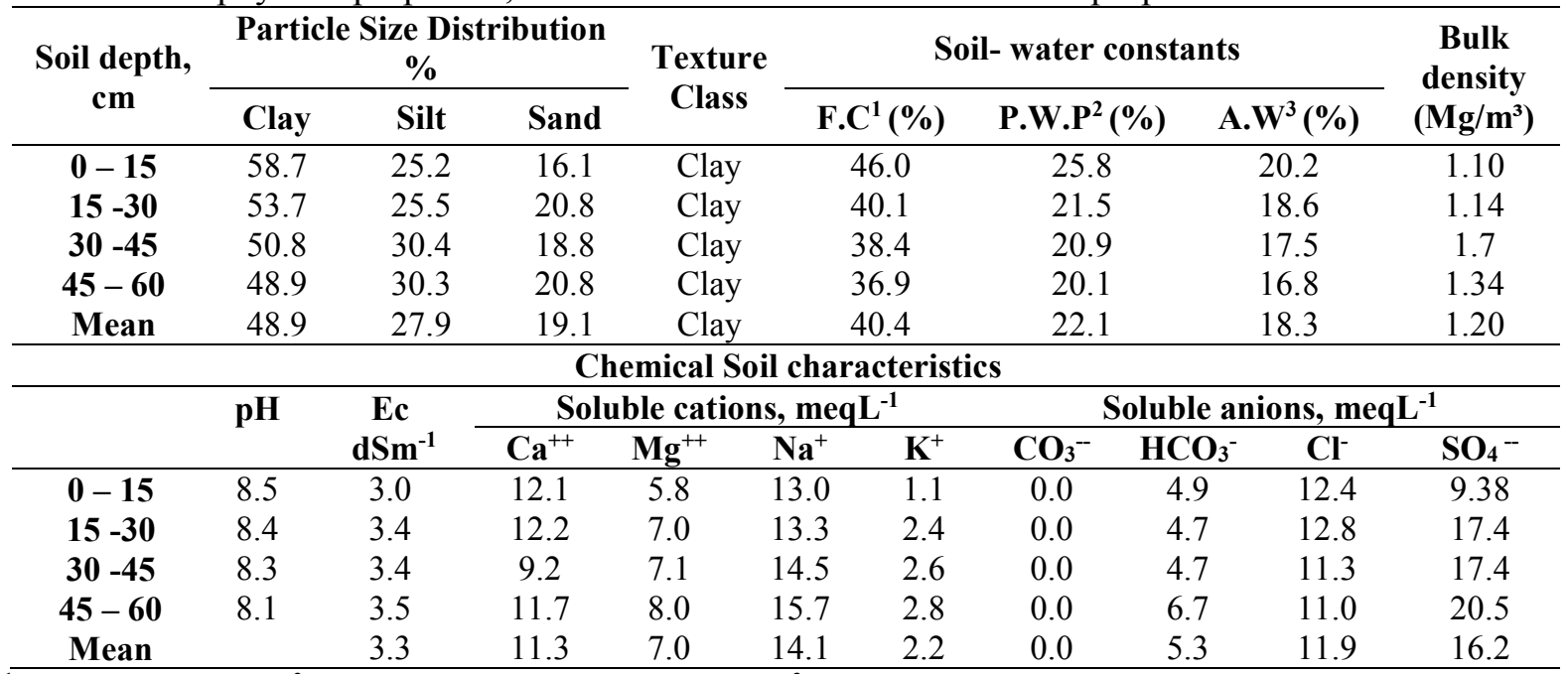

${ }^{1} \mathbf{F C}=$ Field capacity, ${ }^{2} \mathbf{P W P}=$ Permanent wilting point and ${ }^{3} \mathbf{A W}=$ Available soil water 


\section{Irrigation requirement consumption and water supply}

Two experiments of irrigation, The first Irrigation treatment (control experiment) was irrigated two times after planting irrigation and the time period between each two irrigates was one month, while the second treatment (water deficit conditions) was given planting irrigation only until harvesting. Water applied to the plots at each irrigation was equal to the difference between moisture at the field capacity and the soil moisture content at irrigation time of each irrigation (for each irrigation treatment) plus $10 \%$ of quantity to ensure a good uniform distribution of water through the plots.

\section{Phenotypic data analysis}

A homogeneity test of experimental error was calculated before analysis according to Bartlett test (Bartlett, 1937). Analysis of variance (ANOVA), appropriate for the specified experimental design, was performed with MSTATC (version 2.10) computer program written by Freed et al., (1987). Differences among means were tested by least significant difference (LSD) test at 5\% probability level. A combined analysis was performed for each trait over the two seasons.

\section{Molecular Markers}

\subsection{DNA Extraction and SSR-PCR reaction}

Genomic DNA of the 15 barley cultivars was extracted from young leaves using CTAB method according to Doyle and Doyle (1990). DNA concentration was measured using Nanodrop (ND-1000 Spectrophotometer). Polymerase chain reaction (PCR) amplification for SSR markers using ten microsatellite primer pairs previously mapped the barely chromosomes (Grain Genes database) were used in this study was prepared in volume of $25 \mu \mathrm{l}$ using $40 \mathrm{ng}$ of genomic DNA, $2 \mu$ mol dNTP., 25 $\mathrm{mM}$ of $\mathrm{MgCl} 2,10 \mathrm{pmol}$ of each primer (forward and reverse), and a $0.5 \mu 1$ of $5 \mathrm{U}$ of Taq polymerase and $12 \mu \mathrm{l}$ of $10 \mathrm{X}$ PCR buffer. PCR was carried out as the following program; one cycle at $95 \mathrm{C}$ for 5 min., then 35 cycles was performed as follow: $1 \mathrm{~min}$. at $95 \mathrm{C}$ for denaturation, $45 \mathrm{sec}$. at ( $45-55 \mathrm{C}$ for annealing based on primer and $30 \mathrm{sec}$. at $72 \mathrm{C}$ for extension, then incubated at $72 \mathrm{C}$ for $7 \mathrm{~min}$, Amplified products were separated using agarose gel electrophoresis (2\%) in $0.5 \times$ TBE buffer against 100 bp DNA Ladder.

\section{Molecular markers data analysis:}

The amplified bands from SSR were scored as a binary data under the heading of total scorable fragments which determined for each cultivar. The data were used to calculate allele frequencies, allele number, polymorphism information content (PIC), and genetic similarity coefficients (GSC) according to Nei (1973). The genetic similarity coefficients matrix was used to construct a typical cluster scheme revealing associations among Egyptian barley cultivars based on the un-weighted pair group method with arithmetic averages (UPGMA) with bootstrapping 100 times using the PAST program (Hammer et al., 2001).

\section{Results and Discussion}

\section{Analysis of variance}

The combined data analysis of variance for proline content $\left(\mathrm{mgFwg}^{-1}\right)$ chlorophyll content (SPAD), number of tillers $\mathrm{m}^{-2}, 1000$ grain weight (g), grain yield( $\left.\operatorname{ardfed}^{-1}\right)$ showed that there was effect of significant and highly significant affected by years, water stress treatments and cultivars as showhen in Table 4. These results were agreed with some investigations which have been frequently confirmed drought (water stress ) in barley (El Rabey et al., 2012; Mariey et al., 2017; Khatab et al., 2019 and S.A.A. Heiba et al., 2019) which they found there were a significant and highly significant for some traits affected by water stress conditions.

\section{Effect of water stress on water index of yield barely cultivars}

Water stress reduced all the Mean values of water relations such as water applied (wa),water consumptive use (CU), Productivity of water applied (PWa) and Water productivity (WP) as shown in Table 5. Data indicated that the CU was reduced by $35.2 \%$, while water applied was the same under all cultivars of normal $\left(1269.4 \mathrm{~m}^{3} \mathrm{fed}^{-1}\right)$ and under water stress $\left(773.4 \mathrm{~m}^{3} \mathrm{fed}^{-1}\right)$ in average two seasons. 
Table 4: The analysis of variance for five characteristics of 15 barley cultivars combined over the two seasons.

\begin{tabular}{lclllll}
\hline Source & Df & $\begin{array}{l}\text { Proline content } \\
\left(\mathbf{m g F W g}^{-1}\right)\end{array}$ & $\begin{array}{l}\text { Chlorophyll } \\
\text { Content( SPAD) }\end{array}$ & $\begin{array}{l}\text { Means square } \\
\text { No. of tillers } \\
\mathbf{m}^{-2}\end{array}$ & $\begin{array}{l}\text { 1000 grain } \\
\text { weigh t(g) }\end{array}$ & $\begin{array}{l}\text { Grain yield } \\
\text { (ardfed }\end{array}$ \\
\hline Cultivars (C) & 14 & $304.85^{*}$ & $98.04^{* *}$ & $147833.09^{* *}$ & $254.26^{* *}$ & $48.93^{* *}$ \\
years (Y) & 1 & $6.196^{*}$ & $0.117^{*}$ & $444.93^{*}$ & $0.168^{*}$ & $47.34^{* *}$ \\
Treatment(T) & 1 & $5725.7^{*}$ & $709.6^{* *}$ & $1608012.1^{*}$ & $21.29^{* *}$ & $4315.9^{* *}$ \\
C X Y & $\mathbf{1 4}$ & $8.149^{*}$ & $20536^{* *}$ & $2764.35^{* *}$ & $1.83^{*}$ & $2.516^{* *}$ \\
C X T & 14 & $52.70^{*}$ & $10.26^{* *}$ & $21943.3^{* *}$ & $35.36^{* *}$ & $6.4423^{* *}$ \\
Y X T & 1 & $6.837^{*}$ & $9070686^{*}$ & $2698.9^{* *}$ & $0.084^{*}$ & $336.2^{* *}$ \\
CX SX Y & 14 & $2.07^{*}$ & $1.2631^{*}$ & $2064^{* *}$ & $1.004^{*}$ & $1.113^{* *}$ \\
Error & $\mathbf{1 2 0}$ & $\mathbf{3 . 4 5}$ & $\mathbf{1 . 3 8}$ & $\mathbf{6 0 2 . 1 8}$ & & $\mathbf{5 . 3 4}$ \\
\hline
\end{tabular}

Which $\mathrm{Ns},{ }^{*}$ and ${ }^{* *}$ non-significant and significant at the 0.05 and 0.01 levels of probability, respectively.

Table 5: Effect of water stress on water relations of yield barely cultivars.

\begin{tabular}{|c|c|c|c|c|c|c|c|c|c|}
\hline \multirow{2}{*}{ Cultivars } & \multicolumn{3}{|c|}{ Grain yield $\left(\mathrm{kg} \mathrm{fed}^{-1}\right)$} & \multicolumn{3}{|c|}{ CU $\left(\mathrm{m}^{3} \mathrm{fed}^{-1}\right)$} & \multicolumn{3}{|c|}{ Wa $\left(\mathrm{m}^{3} \mathrm{fed}^{-1}\right)$} \\
\hline & $\mathbf{N}$ & $\mathbf{S}$ & $\mathbf{R} \%$ & $\mathbf{N}$ & $\mathbf{S}$ & $\mathbf{R} \%$ & $\mathbf{N}$ & $\mathbf{S}$ & $\mathbf{R} \%$ \\
\hline G. 123 & 2520.0 & 1092.0 & 56.7 & 901.3 & 540.4 & 40.0 & 1269.4 & 773.4 & 39.1 \\
\hline G. 124 & 2184.0 & 888.0 & 59.3 & 753.8 & 464.1 & 38.4 & 1269.4 & 773.4 & 39.1 \\
\hline G. 125 & 2184.0 & 1020.0 & 53.3 & 785.5 & 525.9 & 33.0 & 1269.4 & 773.4 & 39.1 \\
\hline G. 126 & 2328.0 & 1224.0 & 47.4 & 853.7 & 571.3 & 33.1 & 1269.4 & 773.4 & 39.1 \\
\hline G. 127 & 2172.0 & 984.0 & 54.7 & 739.0 & 518.2 & 29.9 & 1269.4 & 773.4 & 39.1 \\
\hline G. 128 & 2496.0 & 1140.0 & 54.3 & 888.6 & 557.9 & 37.2 & 1269.4 & 773.4 & 39.1 \\
\hline G.129 & 1344.0 & 672.0 & 50.0 & 698.2 & 433.1 & 38.0 & 1269.4 & 773.4 & 39.1 \\
\hline G.130 & 2316.0 & 1188.0 & 48.7 & 835.1 & 540.4 & 35.3 & 1269.4 & 773.4 & 39.1 \\
\hline G.131 & 2472.0 & 1464.0 & 40.8 & 875.1 & 580.1 & 33.7 & 1269.4 & 773.4 & 39.1 \\
\hline G. 132 & 1800.0 & 744.0 & 58.7 & 710.9 & 449.7 & 36.7 & 1269.4 & 773.4 & 39.1 \\
\hline G. 133 & 2256.0 & 984.0 & 56.4 & 821.9 & 515.9 & 37.2 & 1269.4 & 773.4 & 39.1 \\
\hline G. 134 & 2388.0 & 1116.0 & 53.3 & 862.7 & 546.1 & 36.7 & 1269.4 & 773.4 & 39.1 \\
\hline G. 135 & 2004.0 & 960.0 & 52.1 & 723.6 & 501.8 & 30.7 & 1269.4 & 773.4 & 39.1 \\
\hline G. 136 & 2232.0 & 1056.0 & 52.7 & 794.9 & 532.5 & 33.0 & 1269.4 & 773.4 & 39.1 \\
\hline G. 2000 & 2568.0 & 1500.0 & 41.6 & 914.0 & 593.5 & 35.1 & 1269.4 & 773.4 & 39.1 \\
\hline Average & 2217.6 & 1068.8 & 52.0 & 810.5 & 524.7 & 35.2 & 1269.4 & 773.4 & 39.1 \\
\hline
\end{tabular}

Table 5: Continued

\begin{tabular}{|c|c|c|c|c|c|c|}
\hline \multirow[t]{2}{*}{ Cultivars } & \multicolumn{3}{|c|}{$\begin{array}{c}\text { PWa } \\
\left(\mathrm{kg} \mathrm{m}^{-3}\right)\end{array}$} & \multicolumn{3}{|c|}{$\begin{array}{c}\text { WP } \\
\left(\mathrm{kg} \mathrm{m}^{-3}\right)\end{array}$} \\
\hline & $\mathbf{N}$ & $\mathbf{S}$ & $\mathbf{R} \%$ & $\mathbf{N}$ & $\mathbf{S}$ & $\mathbf{R} \%$ \\
\hline G. 123 & 2.0 & 1.4 & 29.1 & 2.1 & 2.0 & 2.9 \\
\hline G. 124 & 1.7 & 1.2 & 33.1 & 2.9 & 1.9 & 34.1 \\
\hline G. 125 & 1.7 & 1.3 & 23.3 & 2.8 & 1.9 & 30.2 \\
\hline G. 126 & 1.8 & 1.6 & 13.7 & 2.7 & 2.1 & 21.6 \\
\hline G. 127 & 1.7 & 1.3 & 25.7 & 2.9 & 1.9 & 35.4 \\
\hline G. 128 & 2.0 & 1.5 & 25.4 & 2.8 & 2.0 & 27.4 \\
\hline G.129 & 1.1 & 0.9 & 17.9 & 1.9 & 1.6 & 19.7 \\
\hline G.130 & 1.8 & 1.5 & 15.4 & 2.8 & 2.2 & 20.6 \\
\hline G.131 & 2.0 & 1.9 & 3.1 & 2.8 & 2.5 & 10.6 \\
\hline G. 132 & 1.4 & 1.0 & 32.4 & 2.5 & 1.7 & 34.8 \\
\hline G. 133 & 1.8 & 1.3 & 28.7 & 2.7 & 1.9 & 30.3 \\
\hline G. 134 & 1.9 & 1.4 & 23.4 & 2.8 & 2.0 & 26.4 \\
\hline G. 135 & 1.6 & 1.2 & 21.5 & 2.8 & 1.9 & 31.0 \\
\hline G. 136 & 1.8 & 1.4 & 22.2 & 2.8 & 2.0 & 29.5 \\
\hline G. 2000 & 2.0 & 1.9 & 4.0 & 2.8 & 2.5 & 10.0 \\
\hline Average & 1.7 & 1.4 & 21.3 & 2.7 & 2.0 & 24.3 \\
\hline
\end{tabular}

CU: water consumptive use, Wa: Water applied, PWa: Productivity of water applied and WP: Water Productivity 
Reduction in productivity of water applied $\left(\mathrm{kgm}^{-3}\right) \mathrm{PWa}$ as compared to the normally irrigated cultivars by was $46.6 \%$ and the results showed that Giza 131 and Giza 2000 recorded the lowest reduction in PWa were (3.1 and $4.0 \%$ ) respectively, while the most sensitive cultivar with high reduction $(33.1 \%)$ was recorded by Giza 124 . Also water stress caused reduced in Water productivity $\left(\mathrm{kgm}^{-3}\right)$ WP with average $(24.3 \%)$ which the results showed that G123 recorded the lowest reduction was $2.9 \%$, while the most sensitive one with high reduction (35.4\%) recorded by Giza 127 . These results were in agreements with Shirazi et al., (2014) and Said et al., (2015) who reported that water stress reduced the PWa and WP and explained that the genotype which use water more efficiently could produce maximum biomass.

\section{Combined Performance of Egyptian barley cultivars}

Water stress reduced number of tillers $\mathrm{m}^{-2}$ by $30.8 \%$ as an average for all cultivars once compared with irrigated conditions (Table 6). Results showed that the Giza 2000 and Giza 131 had the highest number of tillers $\mathrm{m}^{-2}$ under irrigated and water stressed conditions during both growing seasons, while the lowest number of tillers $\mathrm{m}^{-2}$ was shown by Giza 130 under irrigated and water stressed conditions.

As same time water stress at grain filling was harmfully affected 1000 grain weight (g), which the reductions among all the cultivars under water stress ranged from highest reduction $25.5 \%$ in Giza 135 to lowest reduction $3.9 \%$ found in Giza 127 with an average reduction for all cultivars $52.1 \%$. data showed that Giza 131,Giza 2000 and Giza 126 had the high values of 1000 grain weight under both irrigation and water stressed conditions .

Table 6: Combined Performance of No. of tillers $\mathrm{m}-2,1000$ grain weight(g), Grain yield, Chlorophyll Content and proline content of Egyptian barley cultivars over the two 2017/2018and 2018/2019 seasons.

\begin{tabular}{|c|c|c|c|c|c|c|c|c|c|c|c|c|c|c|c|}
\hline \multirow[t]{2}{*}{ Cultivars } & \multicolumn{3}{|c|}{$\begin{array}{l}\text { No. of tillers } \\
\left(\mathbf{m}^{-2}\right)\end{array}$} & \multicolumn{3}{|c|}{$\begin{array}{l}1000 \text { grain weight } \\
\text { (g) }\end{array}$} & \multicolumn{3}{|c|}{$\begin{array}{l}\text { Grain yield } \\
\left.\text { (ardfed }^{-1}\right)\end{array}$} & \multicolumn{3}{|c|}{$\begin{array}{c}\text { Chlorophyll } \\
\text { Content } \\
\text { (SPAD) } \\
\end{array}$} & \multicolumn{3}{|c|}{$\begin{array}{l}\text { Proline content } \\
\left(\mathrm{mg} \mathrm{FWg}^{-1}\right)\end{array}$} \\
\hline & $\mathbf{N}$ & $\mathbf{S}$ & $\mathrm{R} \%$ & $\mathbf{N}$ & $\mathbf{S}$ & $\mathrm{R} \%$ & $\mathbf{N}$ & $\mathbf{S}$ & R\% & $\mathbf{N}$ & $\mathbf{S}$ & $\mathrm{R} \%$ & $\mathbf{N}$ & $\mathbf{S}$ & $\mathrm{R} \%$ \\
\hline G. 123 & 455.8 & 314.0 & 31.1 & 57.8 & 46.0 & 20.5 & 21.0 & 9.1 & 56.9 & 47.8 & 44.9 & 6.1 & 41.3 & 49.2 & -24.7 \\
\hline G. 124 & 495.5 & 300.8 & 39.3 & 51.7 & 41.7 & 19.4 & 18.2 & 7.4 & 59.2 & 46.6 & 42.8 & 8.2 & 39.7 & 50.2 & -26.4 \\
\hline G. 125 & 526.3 & 365.8 & 30.5 & 54.3 & 49.4 & 8.9 & 18.2 & 8.5 & 53.4 & 48.7 & 46.7 & 4.1 & 43.7 & 51.2 & -17.2 \\
\hline G. 126 & 564.2 & 438.3 & 22.3 & 58.3 & 51.5 & 11.6 & 19.4 & 10.2 & 47.7 & 49.3 & 45.6 & 7.6 & 43.6 & 51.5 & -14.2 \\
\hline G. 127 & 573.3 & 375.2 & 34.6 & 50.7 & 48.7 & 3.9 & 18.1 & 8.2 & 55.0 & 43.1 & 40.0 & 7.2 & 33.2 & 48.2 & -45.2 \\
\hline G. 128 & 607.0 & 419.2 & 31.0 & 51.4 & 47.5 & 7.5 & 20.8 & 9.5 & 54.2 & 45.8 & 42.6 & 6.8 & 32.5 & 42.5 & -30.8 \\
\hline G.129 & 466.7 & 328.3 & 29.6 & 56.4 & 45.9 & 18.7 & 11.2 & 5.6 & 49.8 & 42.1 & 35.3 & 16.0 & 28.8 & 40.8 & -41.7 \\
\hline G.130 & 343.8 & 265.8 & 22.7 & 52.9 & 42.7 & 19.2 & 19.3 & 9.9 & 48.6 & 47.5 & 44.5 & 6.3 & 41.3 & 48.9 & -18.4 \\
\hline G.131 & 649.2 & 457.5 & 29.5 & 60.2 & 55.8 & 7.3 & 20.6 & 12.2 & 40.8 & 50.7 & 46.5 & 8.3 & 44.9 & 52.8 & -17.6 \\
\hline G. 132 & 468.3 & 305.8 & 34.7 & 46.1 & 37.0 & 19.7 & 15.0 & 6 & 58.9 & 45.5 & 37.2 & 18.2 & 34.4 & 41.5 & -20.6 \\
\hline G. 133 & 603.3 & 311.7 & 48.3 & 51.8 & 44.3 & 14.6 & 18.8 & 8.2 & 56.5 & 46.7 & 42.5 & 9.1 & 33.0 & 54.1 & -63.9 \\
\hline G. 134 & 557.5 & 315.0 & 43.5 & 55.1 & 45.5 & 17.3 & 19.9 & 9.3 & 53.4 & 47.0 & 44.0 & 6.4 & 31.2 & 47.7 & -52.9 \\
\hline G. 135 & 340.0 & 313.2 & 7.9 & 51.9 & 38.7 & 25.5 & 16.7 & 8.0 & 52.4 & 45.5 & 44.3 & 2.5 & 26.1 & 41.8 & -60.2 \\
\hline G. 136 & 486.7 & 351.7 & 27.7 & 48.7 & 40.8 & 16.3 & 18.6 & 8.8 & 53.0 & 50.1 & 46.2 & 7.9 & 37.8 & 49.8 & -31.7 \\
\hline G. 2000 & 663.5 & 465.8 & 29.8 & 56.3 & 52.0 & 7.7 & 21.4 & 12.5 & 41.5 & 51.3 & 45.0 & 12.2 & 44.8 & 54.7 & -22.1 \\
\hline Average & 520.1 & 355.2 & 30.8 & 53.8 & 45.8 & 14.6 & 18.5 & 8.9 & 52.1 & 47.2 & 43.2 & 8.5 & 37.1 & 48.4 & -32.5 \\
\hline
\end{tabular}

In addition, water stress treatment caused reducing in grain yield $\left(\operatorname{ardfed}^{-1}\right)$ in all cultivars under study as compared to the normally irrigated cultivars by $52.1 \%$. Data in (Table 6) showed that Giza 2000 and Giza 131 had the maximum values under normal and stress during the two growing seasons. On the other hand, Giza 129 had the minimum values under normal and stress conditions in both growing seasons. Yield reductions among cultivars ranged from $41.5 \%$ for Giza2000 to 59.2\% grain yield reduction for Giza 124 . 
According to the effect of water stress on physiological traits, the data showed that water stress cases a reduction on total chlorophyll content (SPAD) by the average of was $8.5 \%$ as overall average of all cultivars, which the total chlorophyll content was reduced from $47.2 \%$ in irrigation conditions to $43.2 \%$ in non-irrigation (Table 6). Results showed that Giza 126, Giza131 and Giza 136 had high values of total chlorophyll content among all test cultivars under stress conditions.

Although, water stress cases increased on proline content $\left(\mathrm{mgFwg}^{-1}\right)$ in all cultivars compared by irrigated cultivars under normal conditions, Proline content in all 15 barley cultivars under investigation showed the highest relative increase in response to water stress. The resulted in Table 6 showed that the Egyptian cultivars Giza 2000, Giza 131 and Giza 126 had the highest in porline accumulation among the other cultivars under water stress were $\left(54.7,54.1\right.$ and $\left.52.5 \mathrm{mg} \mathrm{FWg}^{-1}\right)$ respectively

Water deficit reduces plant growth, development and the productivity of many crops (Farooq et al., 2009). In the current study, water stress treatments caused significant reduction in all evaluated agronomic traits. In this regard, water stress during the grain-filling period reduced grain yield by decreasing the number of tillers $\mathrm{m}^{-2}$ and 1000 grain weight, as it is more critical phase and results in substantial yield losses. Similar observations have been reported in many studies of the water stress response of barley (El Rabey et al., 2012; Mariey et al., 2017; Mariey et al., 2018; Khatab et al., 2019; and Hellal et al., 2019), Which they reported that Water stress treatments imposed at different growth stages reduced significantly the grain yield and yield components.

Regarding total chlorophyll content, in our study we found that water stress had reduced the total Chl content in all cultivars under study. Similar investigations have been studies the response water stress barley such as (Filek et al., 2015; Mariey et al., 2017; Saade et al., 2018; khatab et al., 2019 and Marchetti et al., 2019) which They established that under water stress conditions, barley displays reduced chlorophyll content. However, the mechanisms that confer water stress tolerance and recovery capacity in this crop species are still not fully understood.

Water deficit significantly increased the proline content of all Egyptian barley from to a maximum (54.7 mg FWg ${ }^{-1}$ ) found in Giza 2000 to minimum (23.1 $\mathrm{mg} \mathrm{FWg}^{-1}$ ) under well-irrigated treatment. Similar comments have been reported in many studies of the water stress response of proline accumulation in barley (Mamnouie et al., 2006; Mariey et al., 2017; Saade et al., 2018 ;khatab et al., 2019 and Marchetti et al., 2019), which they reported that the plants had a strategy to cope with water-induced stress is to product and accumulate Free Amino Acids in the cell such as proline content which it act as a compatible solute that adjusts the osmotic potential in the plants under stress.

\section{Molecule Marker Analysis}

\subsection{Diversity Analysis}

Ten SSR primer pairs previously mapped on the barely chromosomes (Grain Genes database) were used in this study. These primers were screened against fifteen Egyptian barley cultivars in an attempt to detect polymorphic markers. Four primers showed monomorphic fragment profiles as one marker were Bmac 0209 (3H), Bmag0211( 1H ), Bmag $0125(2 \mathrm{H})$ and Bmac135(7H ), three primers produced two markers were EBmac 0755(7H,Fig1 ),HvM67 (4H) and EBmac 0788( 4H,Fig 1), two primers produced three markers GBM1045 $(3 \mathrm{H})$ and Bmag $0378(5 \mathrm{H})$ and the SSR primer EBmac624 (6H) primer produced four markers Fig (1).

Twenty alleles were produced as a result of fingerprinting ten SSR primers ranging from one to four alleles per locus with a mean value of 2.0 alleles per locus as shown in Table 8 . The PIC (Polymorphism Information Content) value of each SSRs marker measure the marker ranged from 0.23 (HvM67) to 0.58 (EBmac624) with an average value of 0.227 (Table 7). The primers with high value of PIC were sufficient to differentiate all of the studied cultivars 


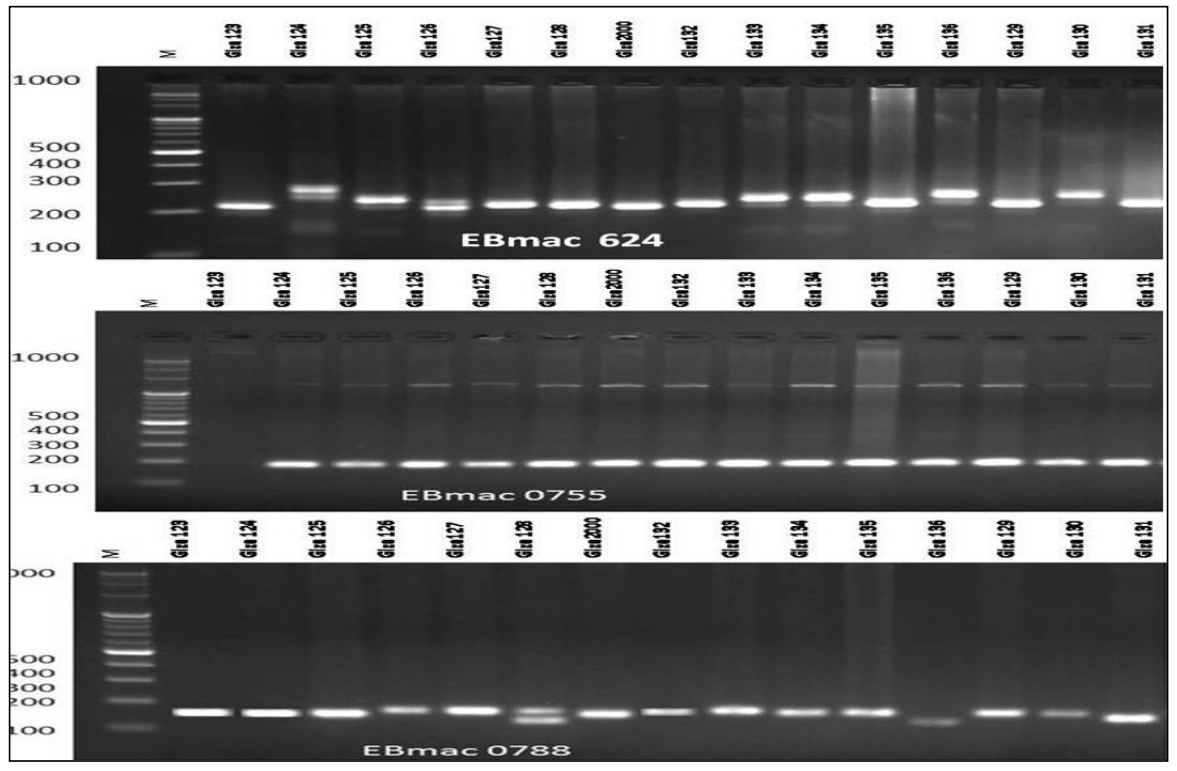

Fig 1: Agarose gel showing banding patterns of SSR marker for 15 barley cultivars

Table 7: List of multiplexing sets of the used SSR primers, chromosome location, position, motifs, no. of alleles and polymorphism information contents (PIC).

\begin{tabular}{|c|c|c|c|c|c|c|}
\hline Primer name & Sequence & $\begin{array}{c}\text { Chromosome } \\
\text { Location }\end{array}$ & $\begin{array}{l}\text { No. of } \\
\text { alleles }\end{array}$ & $\begin{array}{c}\text { No. of } \\
\text { polymorphic } \\
\text { bands }\end{array}$ & PIC & $\begin{array}{c}\text { Polymorphism } \\
\%\end{array}$ \\
\hline Bmag0211 & $\begin{array}{l}\text { F:ATTCATCGATCTTGTATTAGTCC } \\
\text { R: ACATCATGTCGATCAAAGC }\end{array}$ & $1 \mathrm{H}$ & 1 & 0 & 0.0 & 0.0 \\
\hline Bmag 0125 & $\begin{array}{l}\text { F:AATTAGCGAGAACAAAATCAC } \\
\text { R:AGATAACGATGCACCACC }\end{array}$ & $2 \mathrm{H}$ & 1 & 0 & 0.0 & 0.0 \\
\hline GBM1045 & $\begin{array}{l}\text { F- TACACGCACTGAAAAGACGG } \\
\text { R- CTCGCTGCTGAGTTTGTCTG }\end{array}$ & $3 \mathrm{H}$ & 3 & 3 & 0.47 & 100 \\
\hline Bmac0209 & $\begin{array}{l}\text { F:CTAGCAACTTCCCAACCGAC } \\
\text { R:ATGCCTGTGTGTGGACCAT }\end{array}$ & $3 \mathrm{H}$ & 1 & 0 & 0.0 & 0.0 \\
\hline HVM 67 & $\begin{array}{l}\text { F:GTCGGGCTCCATTGCTCT } \\
\text { R:CCGGTACCCAGTGACGAC }\end{array}$ & $4 \mathrm{H}$ & 2 & 2 & 0.23 & 100 \\
\hline EBmac0788 & $\begin{array}{l}\text { F:TAACTTACTTTATATCCATGGCA } \\
\text { R: ATGATGAGAACTCTTCACCC }\end{array}$ & $4 \mathrm{H}$ & 2 & 2 & 0.26 & 100 \\
\hline Bmag0387 & $\begin{array}{l}\text { F:CGATGACCATTGTATTGAAG } \\
\text { R:CTCATGTTGATGTGTGGTTAG }\end{array}$ & $5 \mathrm{H}$ & 3 & 3 & 0.39 & 100 \\
\hline EBmac 624 & $\begin{array}{l}\text { F:AAAAGCATTCAACTTCATAAGA } \\
\text { R: CAACGCCATCACGTAATA }\end{array}$ & $6 \mathrm{H}$ & 4 & 4 & 0.58 & 100 \\
\hline EBmac0755 & $\begin{array}{l}\text { F:AGCCTTGTGTATCAGGACA } \\
\text { R:CTGCTGGTGTTCTCTAAAAGT }\end{array}$ & $7 \mathrm{H}$ & 2 & 2 & 0.34 & 100 \\
\hline Bmag0135 & $\begin{array}{l}\text { F:ACGAAAGAGTTACAACGGATA } \\
\text { R: GTTTACCACAGATCTACAGGTG }\end{array}$ & $7 \mathrm{H}$ & 1 & 0 & 0.0 & 0.0 \\
\hline $\begin{array}{l}\text { Average } \\
\text { Total }\end{array}$ & & & $\begin{array}{c}2 \\
20\end{array}$ & $\begin{array}{c}1.6 \\
16\end{array}$ & $\begin{array}{c}0.227 \\
2.27\end{array}$ & $\begin{array}{c}60 \\
600\end{array}$ \\
\hline
\end{tabular}

\section{Cluster analysis}

Cluster analysis shaped a dendrogram among the 15 Egyptian barley cultivars based on ten SSR fragments using Jukes and Cantor similarity coefficient, which was outlined by the Unweighted Pair-Group Method (UPGMA), the dendrogram (Fig 2) showed that the 15 cultivars were classified into two major groups. The first group divided in two cluster, the first one consisted of three tolerant (T) cultivars ( i.e, Giza 126, Giza131 and Giza 2000 ) and second sub-cluster includes the most moderate tolerance (MT), (i.e, Giza 127, Giza 123, Giza 132, Giza 133, Giza 134, Giza 128and Giza 135). Whereas the second group divided in two cluster the first one consisted of sensitive cultivars (S) such as (Giza 124, and Giza 129) and the other cluster was included the moderate water stress sensitive cultivars (MS) such as (Giza 125, Giza 130 and Giza 136). 


\section{Genetic similarity coefficient matrix}

Genetic similarity coefficient matrix (Table 8) was established by simple matching coefficient using the data generated by the ten expressing primers. These primers enabled us to study the genetic diversity among all the Egyptian barley cultivars for water stress tolerance. The genetic similarity coefficient matrix showed more relation and close in most tolerant cultivars and they are more diverged than other sensitive cultivars. The genetic similarity ranged from low similarity GSC $=(0.39)$ were found between Giza124 and both of Giza127 and Giza 128 which proposes that these were the least-related cultivars to high similarity $\mathrm{GCS}=(0.93)$ were found between Giza2000 and both of Giza131and Giza133, also the high GSC $=(0.93)$ was observed between Giza 126 and Giza131 was $\mathrm{GSC}=(0.92)$ similarity were found between Giza 135 and Giza 134and between Giza 124 and Giza 129, indicating that it was a very close relationship among these cultivars.

Genetic diversity and genetic relationship among barley genotypes for drought (water stress) conditions were investigated using different DNA markers such as RAPD (Nazari and Pakniyat, 2010), ISSR markers (Khatab et al., 2019), SCAR marker (Ben Naceur et al., 2018) and SRAP markers (Mariey et al., 2018 and Hellal et al., 2019). In this experiment, we using SSR marker to study the genetic diversity among 15 Egyptian barley cultivars for water stress tolerance.Twenty alleles were produced as a result of fingerprinting ten SSR primers ranging from one to four alleles per locus with an average value of 2.0 alleles per locus and the average of PIC value was 0.227 that signified these set of SSR markers were favorably informative. Polymorphism Information Content (PIC) is a criterion for assessment of the differentiation power markers. UPGMA methods were used to represent relationship among all Egyptian barley cultivars which classified all fifteen cultivars in two separated major groups. The first group divided in two cluster included tolerant and moderate cultivars, whereas second group divided in two cluster consisted of sensitive and moderate water stress sensitive. Our results were in good harmony with several investigations have been studied for barley for drought ( water stress) using SSR markers such as (Forster et al., 2004; Lakew et al., 2012; El Rabey et al., 2012; Vahideh Gougerdchi et al., 2015 Hellal et al., 2018) whom used SSR markers to investigated genetic diversity and genetic relationship among barley genotypes for drought (water stress) conditions and they reported that the SSRs technique could consider as powerful tool for genetic studies in barley breeding for drought stress.

Therefore our SSRs analysis showed that this technique was informative in a range of barley germplasm which agreed with our morphological data, which provided us useful information on the level of polymorphism and diversity in the Egyptian barley cultivate tolerant to water stress,so we could consider that the two hulled Egyptian cultivars Giza 126, Giza 2000 and the hulled Egyptian barley Giza 131 as a tolerant cultivars under water stress condition (Mariey et al., 2017 \& 2108, and Hellal et al., 2018 \& 2019) found same results and (Ben Naceur et al., 2018) reported that Egyptian naked barley Giza131 could be considered drought tolerant cultivars.

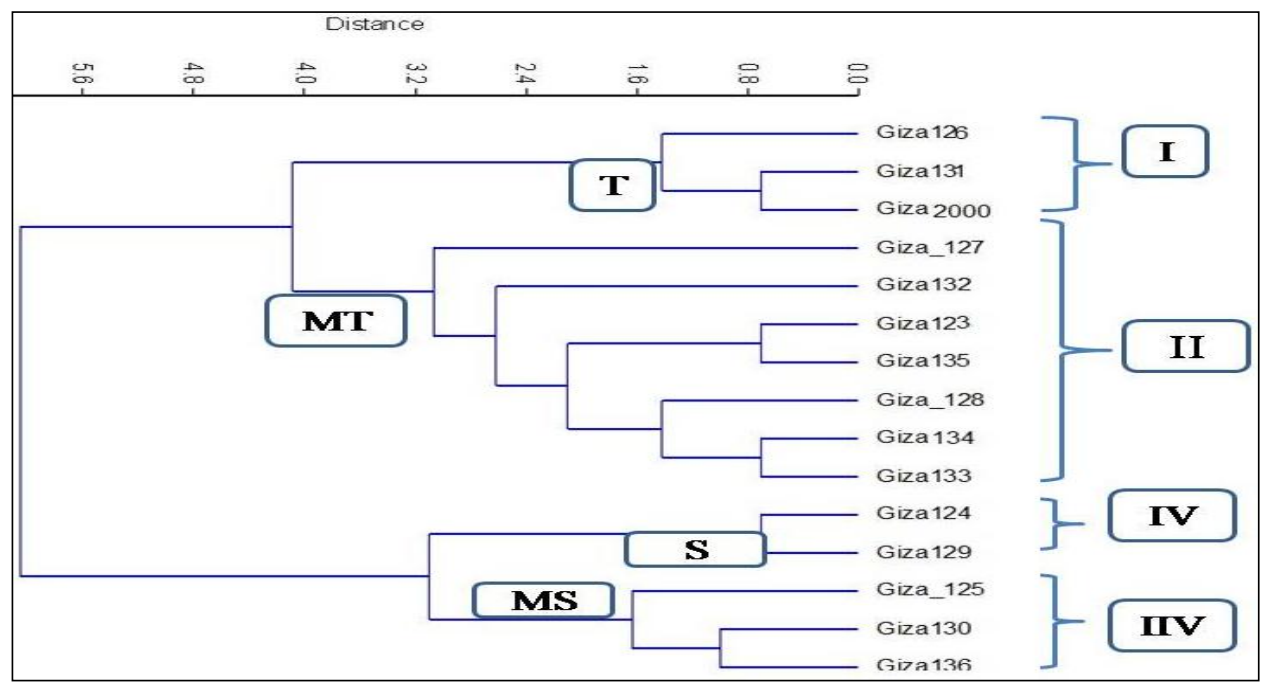

Fig. 2. Dendrogram derived from UPGMA cluster analysis using ten SSR markers 
Table 8: Genetic similarity coefficient matrix for ten SSR primers based on Jukes and Cantor for the studied 15 Egyptian barley cultivars for water stress conditions

\begin{tabular}{|c|c|c|c|c|c|c|c|c|c|c|c|c|c|c|}
\hline Cultivar & $\begin{array}{c}\text { Giza } \\
123\end{array}$ & $\begin{array}{c}\text { Giza } \\
124\end{array}$ & $\begin{array}{c}\text { Giza } \\
125\end{array}$ & $\begin{array}{l}\text { Giza } \\
126\end{array}$ & $\begin{array}{r}\text { Giza } \\
127\end{array}$ & $\begin{array}{r}\text { Giza } \\
128\end{array}$ & $\begin{array}{c}\text { Giza } \\
129\end{array}$ & $\begin{array}{l}\text { Giza } \\
2000\end{array}$ & $\begin{array}{c}\text { Giza } \\
130\end{array}$ & $\begin{array}{c}\text { Giza } \\
131\end{array}$ & $\begin{array}{c}\text { Giza } \\
132\end{array}$ & $\begin{array}{c}\text { Giza } \\
133\end{array}$ & $\begin{array}{c}\text { Giza } \\
134\end{array}$ & $\begin{array}{c}\text { Giza } \\
135\end{array}$ \\
\hline Giza124 & 0.50 & 1.00 & & & & & & & & & & & & \\
\hline Giza125 & 0.64 & 0.53 & 1.00 & & & & & & & & & & & \\
\hline Giza126 & 0.59 & 0.50 & 0.63 & 1.00 & & & & & & & & & & \\
\hline Giza127 & 0.56 & 0.39 & 0.50 & 0.75 & 1.00 & & & & & & & & & \\
\hline Giza128 & 0.67 & 0.39 & 0.60 & 0.75 & 0.73 & 1.00 & & & & & & & & \\
\hline Giza129 & 0.56 & 0.92 & 0.50 & 0.56 & 0.44 & 0.44 & 1.00 & & & & & & & \\
\hline Giza2000 & 0.69 & 0.50 & 0.63 & 0.88 & 0.75 & 0.87 & 0.56 & 1.00 & & & & & & \\
\hline Giza130 & 0.60 & 0.60 & 0.77 & 0.69 & 0.47 & 0.67 & 0.56 & 0.69 & 1.00 & & & & & \\
\hline Giza131 & 0.63 & 0.44 & 0.56 & 0.93 & 0.80 & 0.80 & 0.50 & 0.93 & 0.63 & 1.00 & & & & \\
\hline Giza132 & 0.60 & 0.60 & 0.53 & 0.69 & 0.67 & 0.67 & 0.67 & 0.80 & 0.60 & 0.73 & 1.00 & & & \\
\hline Giza133 & 0.63 & 0.53 & 0.56 & 0.81 & 0.69 & 0.80 & 0.59 & 0.93 & 0.63 & 0.87 & 0.86 & 1.00 & & \\
\hline Giza134 & 0.79 & 0.56 & 0.60 & 0.75 & 0.73 & 0.73 & 0.63 & 0.87 & 0.56 & 0.80 & 0.79 & 0.80 & 1.00 & \\
\hline Giza135 & 0.85 & 0.60 & 0.64 & 0.69 & 0.67 & 0.67 & 0.67 & 0.80 & 0.60 & 0.73 & 0.71 & 0.73 & 0.92 & \\
\hline Giza136 & 0.71 & 0.60 & 0.77 & 0.69 & 0.56 & 0.67 & 0.67 & 0.69 & 0.85 & 0.63 & 0.71 & 0.63 & 0.67 & 0.71 \\
\hline
\end{tabular}

\section{Conclusion}

High genetic differences among15 Egyptian barley cultivars for water stress condition based on the morphological traits, physiological traits and confirmed by selected set of SSRs were investigated in this study. SSRshas generated clear patterns with high polymorphism, this polymorphismas enough to distinguish all cultivars, to discriminate the tolerant and sensitive cultivars. Thus, these genetic differences among Egyptian barley cultivars using SSR marker could be more efficiently to assess genetic variation among them and their ability for tolerance for water stress breeding programs to produce suitable cultivars at normal and water stress condition.

\section{References}

Ali, M.H., M.R. Hoque, A.A. Hassan, and A. Khair, 2007. Effects of deficit irrigation on yield, water productivity and economic returns of wheat. Agricultural Water management, 92(3):151-161.

Bartlett, M.S., 1937. Properties of sufficiency and statistical tests. Proc R Soc Lond A Mat A 160: 268-282.

Ben Naceur, A., S. Mnasri, H. Cheikh-M'hamed, A. Chedly and B.N. M'barek, 2018. Marker-assisted backcrossing for associating nutritional quality to drought tolerance in barley. African Journal of Biotechnology, 17(48):1358-1367.

Bates, I. S., R.P. Waldrn and I.D. Teare, 1973. Rapid determination of free proline for water stress. Plant Soil, 39: 205-207.

Black, C.A., D.D. Evans, J.L. White, L.E. Ensminger and F.E. Clark, 1965. Methods of Soil Analysis. Part 2. Agron. Monogr. 9. Wisconsin, USA: American Society of Agronomy, Madison.

Ceccarelli, S., 1987. Yield potential and drought tolerance of segregation populations of barley in contrasting environments. Euphytica., 36,265-273.

Doyle, J.J. and J.L. Doyle, 1990.A rapid DNA isolation procedure for small quantities of fresh leaf tissue. Focus, 12, 13-15.

El Rabey, A.H., A.Kh. Jalaludin, O.A. Khalid and L.A. Abdulrahman, 2012. Molecular characterization of barley (Hordeum vulgare L.) genome for drought tolerant cultivars selection. African Journal of Biotechnology, 11(40): 9527-9533.

Farooq, M., A. Wahid, N. Kobayashi, D. Fujita and S.M.A. Basra, 2009. Plant drought stress: effects, mechanisms and management. Agron. Sustain. Dev., 29: 185-212

Filek, M., M. Labanowska, J. Kościelniak, J. Biesaga-Kościelniak, M. Kurdziel and I. Szarejko, 2015. Characterization of barley leaf tolerance to drought stress by chlorophyll fluorescence and electron paramagnetic resonance studies. J. Agron. Crop Sci., 201: 228-240.

Forster, B.P., R.P. Ellis, J. Moir, V. Talamè, M. C.Sanguineti, R.Tuberosa, D. This, B. Teulat-Merah, I. Ahmed, S.A. Mariey, H. Bahri, M. El-Ouahabi, N. Zoumarou-Wallis, M.El-Fellah, M.B. 
Salem, 2004. Genotype and phenotype associations with drought tolerance in barley tested in North Africa. Annals of Applied Biology, 144:157-160

Freed, R.P., S.P. Eisensmith, S. Goelz, D. Reicozky, W.W. Smail and P. Woberg, 1987. MSTAT. A Softwar Program for Design, Management and Analysis of Agronomic Research Experiments. Dep. Crop and Soil Sci., Michigan State University, USA.

Hammer, Ø., D.A.T. Harper; P.D. Ryan and PAST, 2001. Paleontological statistics software package for education and data analysis, Palaeontologia Electronica. 4: 1-9.

Hayes, R. B., L.Zhang, S. Yin, J. A. Swenberg, L. Xi, J. Wiencke, and M.T. Smith, 2000. Genotoxic markers among butadiene polymer workers in China. Carcinogenesis, 21: 55-62.

Heiba, S.A.A., A.A.A. Haiba and H.M. Abdel-Rahman, 2019. Determination of Genetic Markers in Some Egyptian Varieties of Wheat and Barley under Salt and Drought Stresses Asian. Crop Sci., 11(2):59-70.

Hellal, F., M. Abdel-Hady, I. Khatab, S. El-Sayed, and A. Chedly, 2019. Yield characterization of Mediterranean barley under drought stress condition. AIMS Agriculture and Food, 4(3): 518-533

Hellal, F.A., H.M. El-Shabrawi, M. Abd El-Hady, I.A. Khatab, S.A.A. El-Sayed and A. Chedly, 2018. Influence of PEG induced drought stress on molecular and biochemical constituents and seedling growth of Egyptian barley cultivars. Journal of Genetic Engineering and Biotechnology $16: 203-212$.

Khatab, I., A. El-Mouhamady, Samah A. Mariey and T. A. Elewa, 2019. Assessment of Water Deficiency Tolerance Indices and their Relation with ISSR Markers in Barley (Hordeum vulgare L.) Curr. Sci. Int., 8(1): 83-100.

Lakew, B., J. Henry, S. Ceccarelli, S. Grando, J. Eglinton and M. Baum, 2012. Genetic analysis and phenotypic associations for drought tolerance in Hordeum spontaneum introgression lines using SSR and SNP markers Euphytica 189, pages9-29.

Mamnouie, E., G. R. Fotouhi, M. Esfahany, and B. Nakhoda, 2006. The Effects of Water Deficit on Crop Yield and the Physiological Characteristics of Barley (Hordeum vulgare L.) Varieties. J. Agric. Sci. Technol., 8: 211-219.

Marchetti, F. C., L. Ugena, J. F. Humplík, M. Polák, S. Zeljkovic C'avar, K. Podlešáková, T. Fürst, N. De Diego, and L. Spíchal, 2019. A Novel Image-Based Screening Method to Study WaterDeficit Response and Recovery of Barley Populations Using Canopy Dynamics Phenotyping and Simple Metabolite Profiling Front. Plant Sci., 10:1252.

Mariey, A. Samah, Mona A.M. El-Mansoury and Maha A. El-Bialy, 2018. Genetic Diversity Study of Egyptian Barley Cultivars using Sequence-Related Amplified Polymorphism (SRAP) Analysis for Water Stress Tolerance J. Sus. Agric. Sci., 43:1 105-114

Mariey, A. Samah and. Khedr A. Rania, 2017. Evaluation of some Egyptian barley cultivars under water stress conditions using drought tolerance indices and multivariate analysis. J. Sus. Agric. Sci., 44(1): 21-37.

Meszaros, K., I. Karsai, C. Kuti, J. Banyai, L. Lang and Z. Bedo, 2007. Efficiency of different marker systems for genotype fingerprinting and for genetic diversity studies in barley (Hordeum vulgare L.). South African Journal of Botany, 43-48,

Nazari, L. and H. Pakniyat, 2010. Assessment of drought tolerance in barley genotypes. J. Appl. Sci. 10:151-156

Nei, M. and W.H. Li, 1979. Mathematical model for studying genetic variation in terms of restriction endonucleases. Proc. Natl. Acad. Sci., 76: 5269-5273

Piper, C.S., 1950. Soil and Plant Analysis. Australia: Adelaide University Hassel Press.

Pirseyedi, S.M., M. Mardi, M.R. Naghavi, H. Poor Iran Doost, D. Sadeghzadeh, S.A. Mohammadi, B. Ghare-yazie, 2006. Evaluation of genetic diversity and identification of informative markers for morphological characters in Sardari derivated wheat lines. Pakistan Journal of Biological Sciences, 9(13):2411-2418.

Russell, J., J.D. Fuller, M. Macaulay, B.G. Hatz, A. Jahoor, W. Powell and R. Waugh, 1997. Direct comparison of levels of genetic variation among barley accessions detected by RFLPs, AFLPs, SSRs and RAPDs. Theoretical and Applied Genetics, 95(4): 714-722

Saade, S., S. Negrão, D. Plett, T. Garnett, and M. Tester, 2018. The Barley Genome. Stein N, Muehlbauer GJ, editors. Cham: Springer International 
Said, A.A., A. Hamada, M. Youssef, N.E. Mohamed and A.A. Mustafa, 2015. SRAP Markers Associated with Water Use Efficiency and Some Agronomic Traits in Wheat under Different Irrigation Regimes. Egypt. J. Agron 37: 209 - 229.

Shirazi, M.U., M.A. Khan, N. Bhatti, A. Unar, H.B. Bozdar, S.M. Mujtaba, and M.I. Lashari, 2014. Growth and water use efficiency in wheat genotypes grown under water stress condition. Journal of Agricultural Research and Development, 4(2):023-028

Vahideh, G., S. Dezhsetan, A. E. Mohammad, B. Sadeghzadeh, and S.Savari, 2014. Using SSR markers for assessment genetic diversity and detection drought escape candidate genes in barley lines (Hordeum vulgare L.) . Plant breeding and Seed Science, 70: 3-14

Wang, W., B. Vinocur and A. Altman, 2003. Plant responses to drought, salinity and extreme temperatures: towards genetic engineering for stress tolerance. Planta, 218: 1-14.

Zhang, X.Y., C.W. Li, L.F. Wang, H.M. Wang, G.X. You and Y.S. Dong, 2002. An estimation of the minimum number of SSR alleles needed to reveal genetic relationships in wheat varieties. Information from large-scale planted varieties and cornerstone breeding parents in Chinese wheat improvement and production. Theoretical and Applied Genetics, 106: 112-117

Zhao, C.X., L.Y. Guo, C.A. Jaleel, H.B. Shoa and H.B. Yang, 2008. Prospect for dissecting plant adaptive molecular mechanisms to improve wheat cultivars in drought environments. International Journal of Agriculture and Biology, 331:579-586. 